\title{
Optimal Hypoxic Preconditioning of Human Embryonic Stem Cell-Derived Mesenchymal Stem Cells (hES-MSCs) and Their Characteristics
}

\author{
Seung Min Lee ${ }^{1}$, Dae Won Jun ${ }^{1,2, *}$, Hyeon Tae Kang ${ }^{1}$, Ju Hee Oh ${ }^{1}$, Waqar Khalid Saeed ${ }^{3}$, Sang Bong Ahn ${ }^{4, *}$ \\ ${ }^{I}$ Department of Translational Medicine, Graduate School of Biomedical Science E Engineering, Hanyang University, Seoul, Korea \\ ${ }^{2}$ Department of Internal Medicine, Hanyang University School of Medicine, Seoul, Korea \\ ${ }^{3}$ Department of Biomedical Sciences, Pak-Austria Fachhochschule: Institute of Applied Sciences and Technology, Mang, Haripur, Pakistan \\ ${ }^{4}$ Department of Internal Medicine, Eulji University School of Medicine, Seoul, Korea
}

Background and Objectives: Hypoxia is frequently used to enhance stem cell function. However, the optimal level of hypoxia for growth and function of human embryonic stem cell-derived mesenchymal stem cells (hES-MSCs) is yet to be determined. The purpose of this study was to find the optimal level of hypoxia for hES-MSCs and characteristics of hES-MSCs cultured under these optimal hypoxic conditions.

Methods and Results: Cell viability and changes in the morphology of hES-MSCs were determined through cell proliferation and CCK-8 assay. The hES-MSCs were preconditioned under various hypoxic conditions $\left(0.5 \sim 5 \% \mathrm{O}_{2}\right.$ and 24 72 h). The expression of cytokines in each culture condition was compared using cytokine array analysis. The morphology of hES-MSCs did not change under various hypoxic culture conditions. hES-MSCs viability after $48 \mathrm{~h}$ incubation in $2 \% \mathrm{O}_{2}$ condition was higher than that in normoxic condition. HIF1 $\alpha$ expression was increased up to six folds after $48 \mathrm{~h}$ of hypoxic preconditioning. HIF1 $\alpha$ expression in hES-MSCs peaked after $48 \mathrm{~h}$ of incubation in $1 \% \mathrm{O}_{2}$ condition. The expressions of PDGF-BB, IGFBP-6, VEGF-A, and angiogenin were increased after hES-MSCs were incubated for $48 \mathrm{~h}$ in $2 \% \mathrm{O}_{2}$ condition.

Conclusions: The hES-MSCs viability and expressions of PDGF-BB, IGFBP-6, VEGF-A, and angiogenin increased after $48 \mathrm{~h}$ incubation in $2 \% \mathrm{O}_{2}$ condition.

Keywords: Hypoxia, Stem cell, Function, VEGF

Received: June 5, 2020, Revised: December 1, 2020, Accepted: January 4, 2021, Published online: February 28, 2021

Correspondence to Dae Won Jun

Department of Internal Medicine, Hanyang University School of Medicine, 17 Haengdang-dong, Sungdong-gu, Seoul 04763, Korea

Tel: +82-2-2290-8338, Fax: +82-2-972-0068, E-mail: noshin@hanyang.ac.kr

Co-Correspondence to Sang Bong Ahn

Department of Internal Medicine, Nowon Eulji Medical Center, Eulji University School of Medicine, 68 Hangeulbiseong-ro, Hagye-dong, Nowon-gu, Seoul 01830, Korea

Tel: +82-2-970-8209, Fax: +82-2-972-0068, E-mail: dr486@eulji.ac.kr

*These authors contributed equally to this work.

다 This is an open-access article distributed under the terms of the Creative Commons Attribution Non-Commercial License (http://creativecommons.org/licenses/by-nc/4.0/), which permits unrestricted non-commercial use, distribution, and reproduction in any medium, provided the original work is properly cited.

Copyright (c) 2021 by the Korean Society for Stem Cell Research 


\section{Introduction}

Stem cells are known for their self-regeneration and differentiation properties which are dependent on various micro-environmental signals including growth factors and mechanical forces. Given such characteristics, stem cell treatment can be considered for use in treatment of diabetes, myocardial infarction, Parkinson's and Alzheimer's diseases as well as other degenerative conditions $(1,2)$.

In recent studies, human embryonic stem cell-derived mesenchymal stem cells (hES-MSCs) have been demonstrated as unlimited sources of stem cells with consistent differentiation capacity and treatment results reported to be stronger than bone marrow mesenchymal stem cells (3, 4). In addition, hES-MSCs have several advantages that make them better candidates for clinical applications including the high rate of proliferation in vitro and lower maturity than that of adult MSCs (5-7).

Stem-cell therapy is expected to be highly efficacious in various diseases; however, after stem cell therapy, only a marginal improvement in damaged tissue is achieved and the effect is not sustained. Among the various methods used for differentiation and functional enhancement of cells, the use of hypoxia has been suggested in numerous studies due to its positive effect on survival, proliferation, and differentiation potential of cells $(8,9)$. In order to achieve hypoxia, cells are exposed to low $\mathrm{O}_{2}$ levels and as a result, cells express different target genes that are regulated by hypoxia-inducible factor $1 \alpha$ (HIF1 $\alpha)$. HIF1 $\alpha$ -induced signal transduction is regulated by direct interaction between angiogenin and promoter regions. Additionally, some reports have suggested that overexpression of HIF $1 \alpha$ induces angiogenesis (10).

Hypoxia plays a crucial role in stem cells functioning; however, there is a lack of consensus regarding this point. The effects of hypoxia differ based on cell type (11). Most studies used single oxygen tension for a fixed duration. Additionally, there are huge discrepancies regarding the pre-culture conditions and duration of hypoxia in various studies. The optimal time of hypoxia application for obtaining maximal paracrine effect is still not known. In a study, hypoxic conditioning for $24 \mathrm{~h}$ showed more potent angiogenic effect in MSCs (12). However, Wang et al. (13) suggested that the viability and angiogenic properties of stem cells are maximized after $10 \mathrm{~min}$ of hypoxic conditioning.

The purpose of this study was to find the optimal level of hypoxia in hES-MSCs and characteristics of hES-MSCs cultured under the optimal level of hypoxia.

\section{Materials and Methods}

\section{Acquisition and culture of hES-MSCs}

hES-MSCs were procured from Daewoong Pharmaceutical (Seoul, Korea). After thawing, hES-MSCs were maintained in GIBCO $^{\mathbb{R}}$ StemPro MSC SFM Xeno-free medium (A1067501, Thermo Fisher Scientific, MA, USA) supplemented with $2 \mathrm{mM}$ L-glutamine (25030081, Thermo Fisher Scientific, MA, USA) and 1\% penicillin (15140122, Thermo Fisher Scientific, MA, USA) at $37^{\circ} \mathrm{C}$ under condition of $21 \% \mathrm{O}_{2}$. The experiments were performed at passage 12 .

\section{Hypoxic culture conditions for hES-MSCs}

After hES-MSCs reached $90 \%$ confluence at passage 11, culture media was removed and cells were washed with 1X Dulbecco's Phosphate-Buffered Saline (DPBS). The cells were then seeded at a density of $1 \times 10^{5}$ cells $/ 60 \mathrm{~mm}^{2}$ dish and incubated for $24 \mathrm{~h}$ under normal conditions $\left(21 \% \mathrm{O}_{2}\right)$. After incubation, culture media was removed and cells were washed with 1X DPBS. Next, cells were treated with normal $\mathrm{O}_{2}$ condition $\left(21 \% \mathrm{O}_{2}\right)$ and low $\mathrm{O}_{2}$ conditions $\left(0.5 \%, 1 \%, 2 \%\right.$, or $\left.5 \% \mathrm{O}_{2}\right)$ before culture. Low $\mathrm{O}_{2}$ conditions were maintained using low $\mathrm{O}_{2}$ tensions of $0.5 \%, 1 \%, 2 \%$, and $5 \% \mathrm{O}_{2}$ for 24,48 , and $72 \mathrm{~h}$. For creating a low $\mathrm{O}_{2}$ environment, a hypoxic chamber (MIC-101, Billups-Rothenberg Inc., San Diego, CA, USA) was used. The final composition of gases in the hypoxic chamber consisted of $5 \% \mathrm{CO}_{2}, \mathrm{O}_{2}\left(0.5 \%, 1 \%, 2 \%\right.$, or $\left.5 \% \mathrm{O}_{2}\right)$, and the remaining volume was filled with $\mathrm{N}_{2}$ gas.

\section{Cell viability assessment}

The hES-MSCs that were cultured for 24, 48, and $72 \mathrm{~h}$ under normal and low $\mathrm{O}_{2}$ conditions were incubated for $4 \mathrm{~h}$ using 1/10 dilution of CCK-8 solution (CK04-13, MD, USA). The optical density was measured at $450 \mathrm{~nm}$ using a microplate absorbance reader (BR168-1135, Bio-Rad Laboratories, Inc., California, USA). Cells were cultured for 24 hours and then induced to a hypoxic state with or without $10 \mu \mathrm{M}$ of HIFla inhibitor (CAY10585, abcam, Cambridge, MA, USA).

\section{Cytokine array}

The conditioned media acquired from normal and low $\mathrm{O}_{2}$ conditions were stored at $-80^{\circ} \mathrm{C}$, and were thawed before use in accordance with manufacturer's guidelines provided by RayBio C-Series Human Cytokine Antibody Array (AAH-CYT-1000-2, Ray Biotech, Norcross, GA, USA). ChemiDoc $^{\text {TM }}$ XRS (Bio-Rad, California, USA) was used for detection and Image Lab software (Bio-Rad, California, USA) was used for quantification. It should be considered 
that this product contains other protein expressions in addition to cytokines.

\section{Western blot}

Cells grown under normal and low $\mathrm{O}_{2}$ conditions were collected in a microtube, and $1 \times$ Cell Extraction Buffer PTR (ab171577, Abcam, Cambridge, UK) was used for protein extraction. The protein extracts were quantified, and $20 \mu \mathrm{g}$ proteins were transferred to sample buffer, separated by $10 \%$ sodium dodecyl sulfate polyacrylamide gel electrophoresis and transferred to PVDF membranes (Immobilon-P; Millipore, Billerica, MA, USA). After blocking with $5 \%$ BSA solution for $1 \mathrm{~h}$, the membrane was incubated with primary antibodies (1:500 dilution) for $12 \mathrm{~h}$ (overnight) at $4^{\circ} \mathrm{C}$. Later, the membrane was incubated with horseradish peroxidase (HRP)-conjugated secondary antibodies (1:3,000 dilution) for $1 \mathrm{~h}$ at $37^{\circ} \mathrm{C}$, after which ChemiDoc ${ }^{\mathrm{TM}}$ XRS (Bio-Rad, California, USA) was used for detection. The list of antibodies used is as follows: anti-hypoxia inducible factor $1 \alpha$ antibody (MAB5 382, Merck Millipore, Darmstadt, Germany), anti-GAPDH antibody (14C10, Cell signaling, Cambridge, UK), goat anti-mouse $\operatorname{lgG}(\mathrm{H}+\mathrm{L})-\mathrm{HRP}$ (SA001, GenDEPOT, Katy, TX, USA), and goat anti-rabbit $\lg \mathrm{G}(\mathrm{H}+\mathrm{L})-\mathrm{HRP}$ (SA002, GenDEPOT, Katy, TX, USA).

\section{Statistical analysis}

Data analysis was performed using the GraphPad Prism statistics software package (GraphPad Software, CA, USA). Cell viability data were presented as mean \pm SEM using One-way ANOVA test with Dunnett's multiple comparisons test, and HIF1 $\alpha$ protein data were presented as mean \pm SD with One-way ANOVA test with Sidak's multiple comparisons test.

Correlation analyses were performed using Pearson correlation coefficient. $\mathrm{p}<0.05$ was considered to indicate a statistically significant difference.

\section{Results}

\section{Morphology and survival rate of hES-MSCs under various hypoxic conditions}

Changes in morphology and survival of hES-MSCs were evaluated under various hypoxic conditions (0.5 5\% oxygen and $24 \sim 72 \mathrm{~h}$ incubation) (Fig. 1A). Cell morphology did not change under various hypoxic conditions, but the survival rate of cells exposed for 24, 48, and 72 hours under hypoxic conditions increased significantly.

In addition, the survival rate of cells increased as the oxygen partial pressure increased during 24 and 48 hours, but at 72 hours, the survival rate decreased slightly at $0.5 \%$ and $1 \% \mathrm{O}_{2}$ compared to the $72 \mathrm{~h}$ normal condition,

$\mathbf{A}$

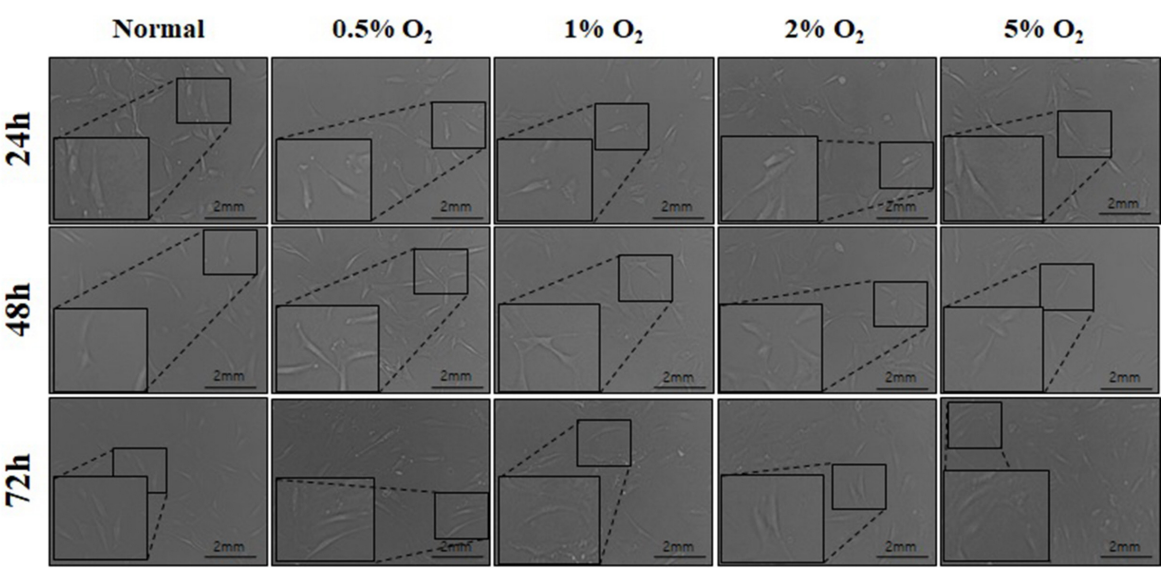

B

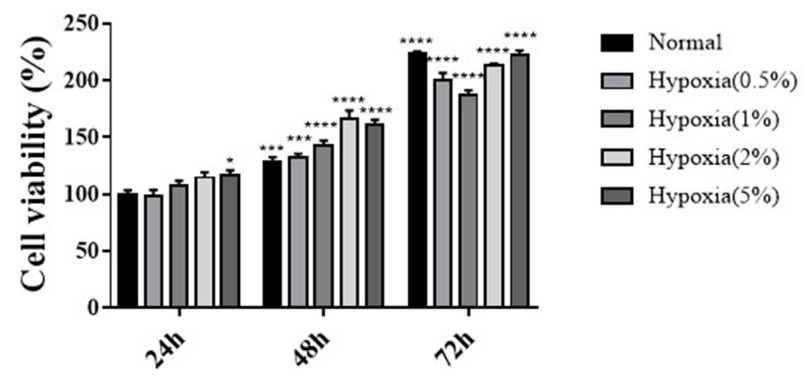

Fig. 1. Morphology and viability of hES-MSCs under normal and hypoxic conditions. (A) Morphological analysis of hES-MSCs cultured under normal $\left(21 \% \mathrm{O}_{2}\right)$ and various hypoxic incubation conditions $(0.5 \%$, $1 \%, 2 \%$, and $\left.5 \% \mathrm{O}_{2}\right)$ for 24,48 and $72 \mathrm{~h}$. The morphology was observed using an optical microscope; Magnification: $400 \times$. (B) Cell viability was assessed using CCK-8 cell viability assay; $\left(\mathrm{n}=6\right.$, mean $\pm \mathrm{SEM}$; $\mathrm{ns},{ }^{*} \mathrm{p}<$ $0.05, * * \mathrm{p}<0.01, * * * \mathrm{p}<0.001$ and $* * * \mathrm{p}<0.0001$ vs. normal condition using One-way ANOVADunnett's multiple comparison test). 
and then increased again at 2\% and $5 \% \mathrm{O}_{2}$. Most of the $72 \mathrm{~h}$ conditions show about $200 \%$ survival rate than $24 \mathrm{~h}$ Normal (Fig. 1B).

\section{HIF1 $\alpha$ protein expression under various hypoxic conditions}

Although excessive hypoxia for prolonged duration reduced cell viability; however, HIF1 $\alpha$ protein expression increased in proportion to the degree of hypoxia. The increase in HIF1 $\alpha$ protein expression was greater in low $\mathrm{O}_{2}$ culture conditions than that in normoxic conditions.
However, the expression of HIF1 $\alpha$ protein did not increase in $5 \% \mathrm{O}_{2}$ condition (Fig. $2 \mathrm{~A}$ and $2 \mathrm{~B}$ ). The expression of HIF1 $\alpha$ protein increased by a maximum of six folds in cells exposed to $0.5 \% \mathrm{O}_{2}$ for $72 \mathrm{~h}$, while it increased four-folds when cells were exposed to $0.5 \sim 1 \% \mathrm{O}_{2}$ for $48 \mathrm{~h}$ (Fig. 2A and 2B). HIF1 $\alpha$ protein expression showed a positive correlation with cell survival (Fig. 2C). In addition, the degree of hypoxia showed a positive correlation with $\mathrm{HIF} 1 \alpha$ protein expression, with maximum HIF1 $\alpha$ expression observed at $1 \% \mathrm{O}_{2}$ (Fig. 2D). We confirmed whether HIFla plays a direct role in cell viability
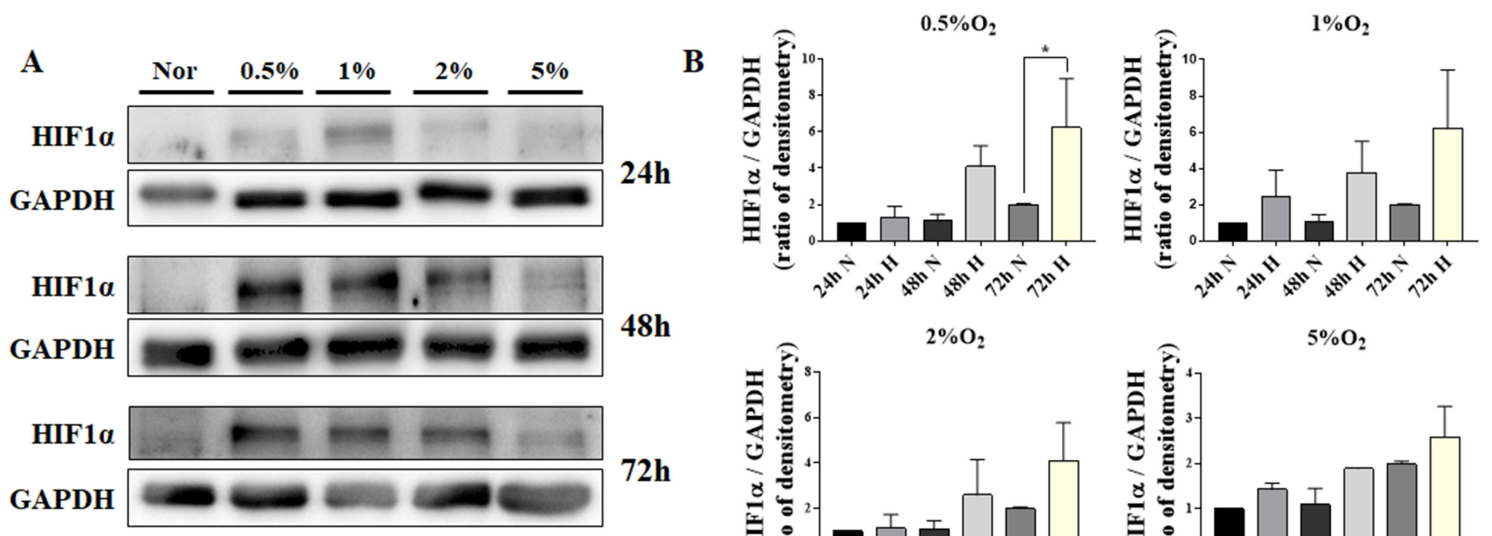

$72 \mathrm{~h}$

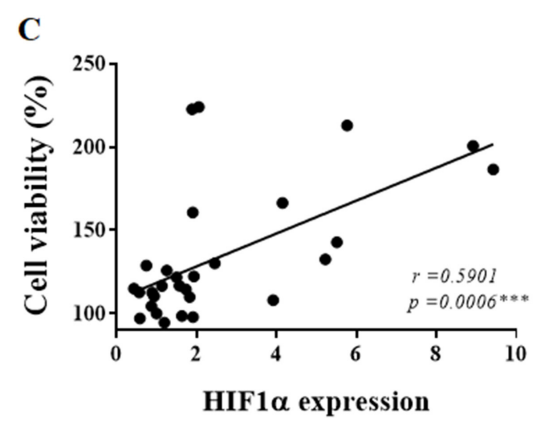

D
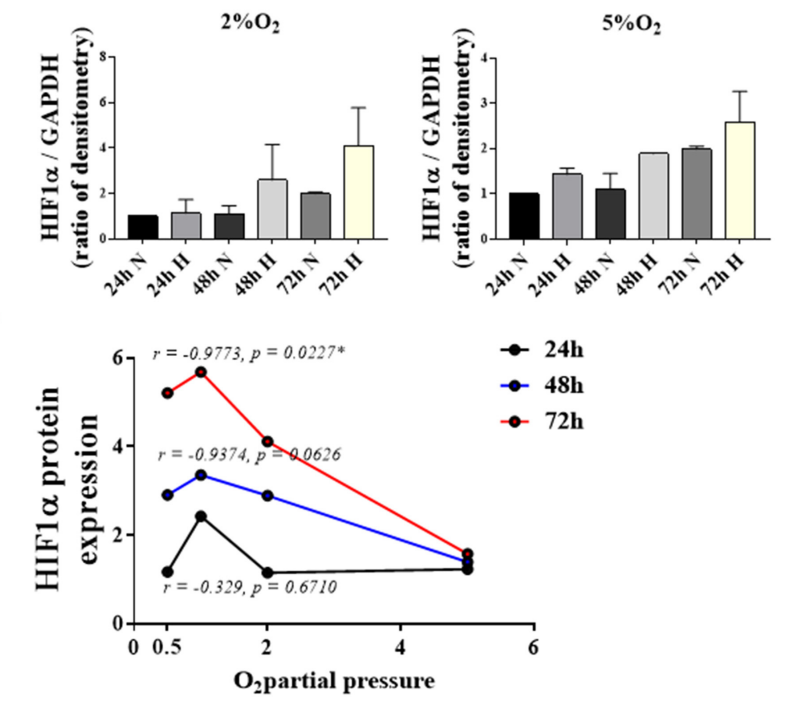

$\mathbf{E}$

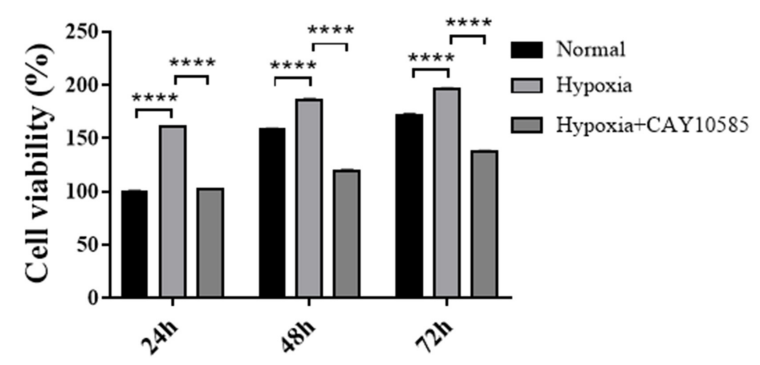

Fig. 2. Correlation between HIF1 $\alpha$ protein expression and cell viability of hES-MSCs under various hypoxic conditions. (A) HIF1 $\alpha$ protein expression under normal and hypoxic conditions. (B) HIF1 $\alpha$ protein quantification using densitometry. (C) Correlation between cell viability and HIF1 $\alpha$ relative expression. (D) HIF1 $\alpha$ protein expression at various low $\mathrm{O}_{2}$ partial pressures. (E) Cell viability comparison with or without HIF1 $\alpha$ inhibitor in hypoxia; $(n=6$, mean \pm SEM; $n s, * p<0.05, * * p<0.01, * * * p<0.001$ and $* * * * p<0.0001$ vs. normal condition using One-way ANOVA-Dunnett's multiple comparison test). 

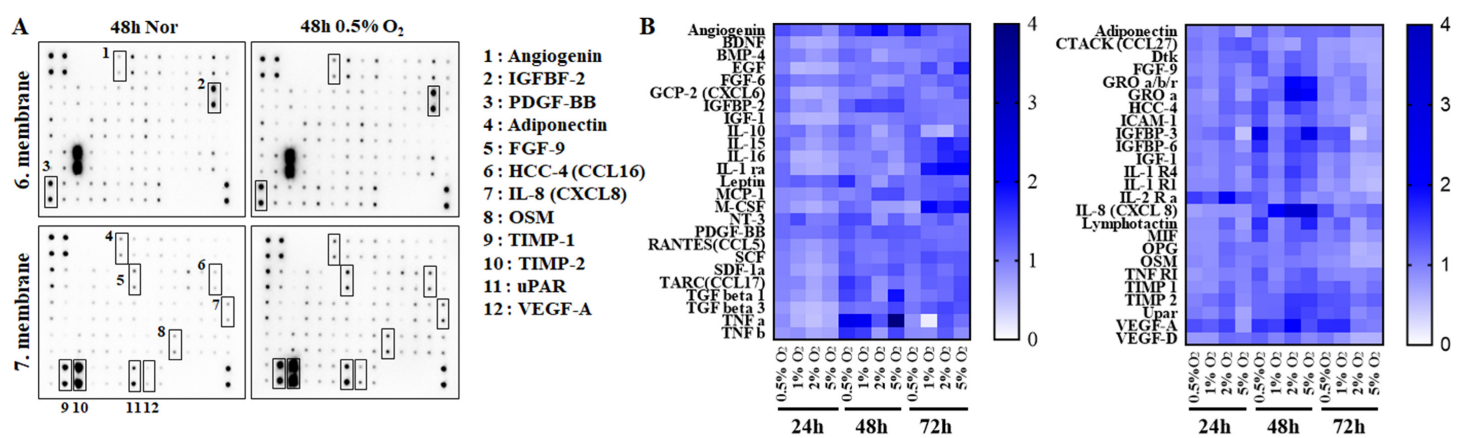

C
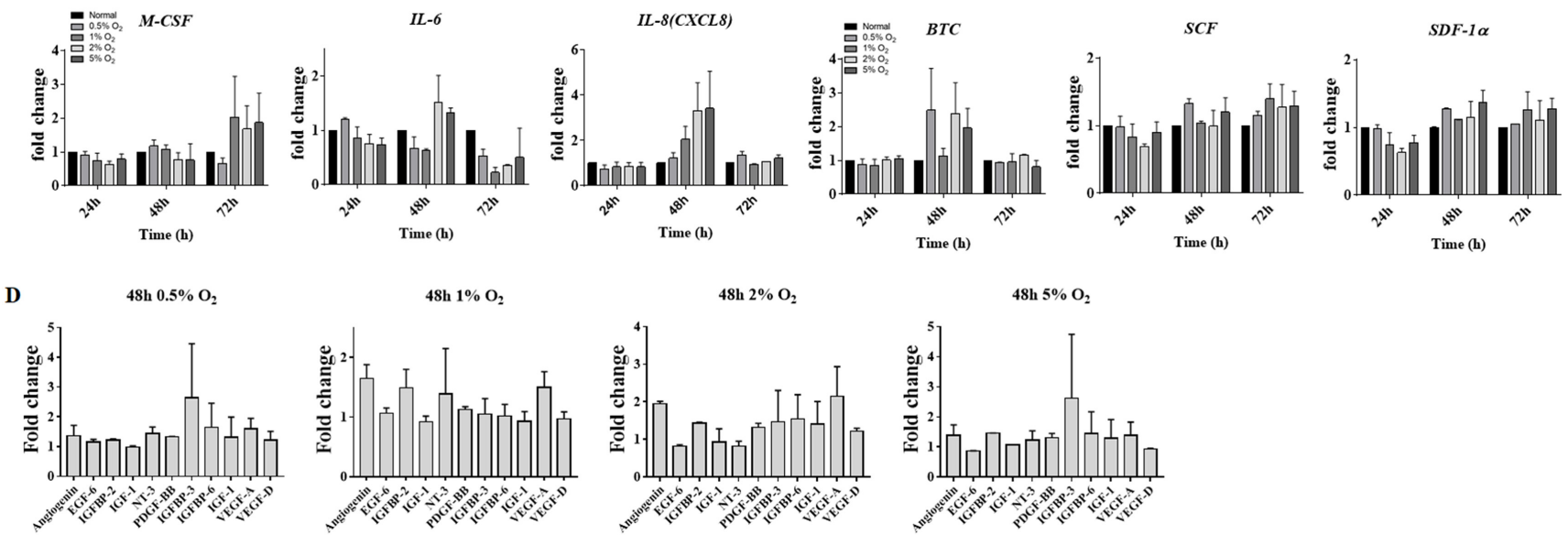

Fig. 3. Comparison of hES-MSCs cytokines expressions under various hypoxic conditions. (A) Membrane after Ray Bio human cytokine antibody array. (B) Heat map demonstrating relative expressions of biomarkers from screening cytokine antibody array in normal vs. various hypoxic conditions. (C, D) Comparison of cytokines expressions in various hypoxic culture conditions.

according to this correlation. First, cell viability gradually increased as time passed in normal condition, and in case of hypoxia, it increased than normal condition. Here, when treated with $10 \mu \mathrm{M}$ of HIF1 $\alpha$ inhibitor CAY10585 and induced to hypoxia, it was confirmed that the survival rate again decreased compared to the cell viability in the hypoxia state (Fig. 2E).

\section{Changes in cytokines expression in hES-MSCs under various hypoxic conditions}

In order to determine the hypoxic culture condition that would enhance hES-MSCs functionality, cytokine array analysis was performed using conditioned media (Fig. $3 \mathrm{~A})$. Changes in cytokine expression in cells cultured under various hypoxic conditions for 48 to $72 \mathrm{~h}$ were observed (Fig. 3B). M-CSF, which is involved in the proliferation and differentiation of monocytes, macrophages and bone marrow progenitor cells, shows approximately 1.8 -fold the expression in cells exposed to $1 \%, 2 \%$, and $5 \% \mathrm{O}_{2}$ compared to $72 \mathrm{~h}$ normal.

IL-6 was expressed 1.5 -fold in $2 \%$ and $5 \% \mathrm{O}_{2}$ at $48 \mathrm{~h}$ but decreased in hypoxia at $72 \mathrm{~h}$. IL-8 (CXCL8) is ob- served to increase depending on the $48 \mathrm{~h} \mathrm{O}_{2}$ partial pressure. In addition, the expression of SCF (KITLG), which is important for hematopoietic and melanogenesis, and SDF-1 $\alpha$ (CXCL12), which mediates the inhibitory effect on osteoclast formation by chemotaxis on mesenchymal stem cells, compared to normal condition increased about 1.3-fold at $48 \mathrm{~h}$ and $72 \mathrm{~h}$. The expression of BTC, which inhibits bone morphogenesis and requires HIF1 $\alpha$, increased its expression by at least 2- to 2.5 -fold at $0.5 \%, 2 \%$, and $5 \% \mathrm{O}_{2}$ at $48 \mathrm{~h}$ (Fig. $3 \mathrm{C}$ ).

The expression of PDGF-BB increased under all the hypoxic conditions. The expressions of IGFBP-3, IGFBP-6, PDGF-BB, VEGF-A, and NT-3 were increased in cells exposed to $0.5 \% \mathrm{O}_{2}$ for $48 \mathrm{~h}$, and expressions of PDGF-BB, IGFBP-6, VEGF-A, and angiogenin were increased in cells exposed to $2 \% \mathrm{O}_{2}$ for $48 \mathrm{~h}$ (Fig. 3D).

\section{Discussion}

Our data showed that the survival rate of cells exposed to $2 \% \mathrm{O}_{2}$ for $48 \mathrm{~h}$ was higher than that of cells grown under normoxic conditions. The expression of HIF1 $\alpha$ 
protein showed a positive correlation with cell survival. PDGF-BB, IGFBP-6, VEGF-A, and angiogenin expressions increased in cells exposed to $2 \% \mathrm{O}_{2}$ for $48 \mathrm{~h}$.

In this study, the survival rate of MSCs did not decrease when exposed to hypoxia compared to normoxia except for above certain concentrations of HIFl $\alpha$. The cell survival rate increased in response to various hypoxic conditions $(1 \sim 5 \%$ for $24 \sim 48 \mathrm{~h})$ compared to that in normoxia. However, at $72 \mathrm{~h} 1 \% \mathrm{O}_{2}$ cell survival decreases, suggesting that excessive HIF1 $\alpha$ expression negatively affects cell survival.

The cytokine array test was performed for each condition to investigate changes in expressions of cytokines under various hypoxic conditions. It was shown that expression of various growth factors such as angiogenin, FGF, PDGF, and VEGF increased the most after $48 \mathrm{~h}$ of incubation. In addition, expression of HIF1 $\alpha$ protein increased under most conditions, especially in cells exposed to $0.5 \%, 1 \%$, and $2 \% \mathrm{O}_{2}$ for $48 \mathrm{~h}$.

The results of this study are in agreement with the results of an earlier study by Luo et al. (14) showed that expression of HIFl $\alpha$ is related to the survival of bone marrow-derived stem cells (BMSCs). When BMSCs were treated with a HIF1 $\alpha$ activator, the apoptosis of BMSCs was reduced. Conversely, when BMSCs were treated with a siRNA against HIF1 $\alpha$, BMSCs underwent apoptosis (14). Liu et al. (15) investigated the exposure of MSCs to various hypoxic conditions $\left(2 \%, 5 \%\right.$, or $\left.7 \% \mathrm{O}_{2}\right)$ for various durations $(24,48$, and $72 \mathrm{~h})$, similar to our study. The expression of VEGF-A, ANG, HIF1 $\alpha$, and MMP-9 increased in cells exposed to $5 \% \mathrm{O}_{2}$ for $48 \mathrm{~h}$. In the results of Liu et al. (15), BM-MSC observed that expression of genes related to angiogenesis increased in cells cultured for $5 \% \mathrm{O}_{2}, 48 \mathrm{~h}$. This suggests that the optimal hypoxic condition may differ based on the type of stem cell.

Although very few studies evaluated how HIF1 $\alpha$ regulates expression of angiogenesis-related genes, Xiong et al. (16) have demonstrated that under conditions of hypoxia, expression of HIF1 $\alpha$ is upregulated, but expression of miR-20a is downregulated. They found that HIF1 $\alpha$ suppresses the expression of miR-20a via binding to its 3'-untranslated region. Subsequently, HIF1 $\alpha$ promoted angiogenesis in adipose-derived stem cells by suppressing miR-20a.

The expression of PDGF-BB, IGFBP-6, VEGF-A, NT-3, and angiogenin was increased in cells exposed to different hypoxic conditions $\left(0.5 \%\right.$ and $\left.1 \% \mathrm{O}_{2}\right) 48 \mathrm{~h}$. PDGF-BB, VEGF-A, NT-3, and angiogenin are all widely known to be important factors affecting survival and regeneration of neuronal cells. Several studies have shown that PDGF-BB,
VEGF-A, NT-3, and angiogenin exhibit protective effects on stroke and Lou Gehrig's disease (ALS) (17). Reinforcing stem cell function by hypoxic preconditioning might be effective in neurodegenerative disease, but further studies are needed to confirm the efficacy of preconditioning the stem cells.

Stem-cell therapy has shown promising results in various diseases; however, only a marginal improvement was achieved in conditions of tissue damage and the effect was not sustained. In order to address these problems, investigators have attempted to improve the efficacy of various treatment methods. Methods of stem cells priming such as inserting a specific gene into a cell, controlling the concentration of chemicals or small peptide, or changing culture environment of cells $\left(\mathrm{O}_{2}\right.$ level, temperature, light, and transplantation) have been suggested to addresses these problems.

However, priming methods have several limitations. First, priming is cost-intensive and may increase immunogenicity. Second, the degree of stem-cell enhancement depends on cell source and condition. Third, the long-term tumorigenic potential of stem cells needs to be clarified. Fourth, studies on increasing cell differentiation capacity through hypoxia have been conducted mainly using model systems such as laboratory animals, and therefore, verification and review are required for reproducibility when employed in humans.

In addition, stem cell therapy with growth factors and cytokines has a variety of functions including stimulating multiple biological changes through cellular signal transduction and binding specific receptors. It has the advantage of incorporating biodegradable scaffolds, hydrogels and other biologically designed platforms to enhance their function, but has the disadvantages of potential immune response to treatment, limited clinical use, and high treatment costs (18).

Hypoxic conditions showed promising results that helped to differentiate stem cells into chondrocytes and cardiomyocytes, and had a positive effect on bone formation. However, the optimal oxygen concentration to stimulate their differentiation is not known (19-22).

Abdollahi et al. (23), cited the difficulty of establishing optimal conditions as the ultimate effect of hypoxia was dependent on several factors, including stem cell line, oxygen partial pressure, duration, and other culture conditions.

In conclusion, hES-MSCs were found to have an optimal therapeutic effect when exposed to $2 \% \mathrm{O}_{2}$ for $48 \mathrm{~h}$. 


\section{Acknowledgments}

This study was funded by the National Research Foundation of Korea (NRF-2017R1C1B5074215) and Daewoong Pharmaceuticals Co., Ltd.

\section{Potential Conflict of Interest}

The authors have no conflicting financial interest.

\section{Author Contributions}

Dae Won Jun contributed to the study design, Seung Min Lee wrote the manuscript, Ju Hee Oh and Hyeon Tae Kang did the molecular work and was involved in data management, Waqar Khalid Saeed and Sang Bong Ahn analysis the data and revising it critically for important intellectual content.

\section{References}

1. Harris DT. Non-haematological uses of cord blood stem cells. Br J Haematol 2009;147:177-184

2. Haque N, Rahman MT, Abu Kasim NH, Alabsi AM. Hypoxic culture conditions as a solution for mesenchymal stem cell based regenerative therapy. ScientificWorldJournal 2013;2013:632972

3. Li O, Tormin A, Sundberg B, Hyllner J, Le Blanc K, Scheding S. Human embryonic stem cell-derived mesenchymal stroma cells (hES-MSCs) engraft in vivo and support hematopoiesis without suppressing immune function: implications for off-the shelf ES-MSC therapies. PLoS One 2013;8:e55319

4. Wang X, Kimbrel EA, Ijichi K, Paul D, Lazorchak AS, Chu J, Kouris NA, Yavanian GJ, Lu SJ, Pachter JS, Crocker SJ, Lanza R, Xu RH. Human ESC-derived MSCs outperform bone marrow MSCs in the treatment of an EAE model of multiple sclerosis. Stem Cell Reports 2014;3:115-130

5. Kern S, Eichler H, Stoeve J, Klüter H, Bieback K. Comparative analysis of mesenchymal stem cells from bone marrow, umbilical cord blood, or adipose tissue. Stem Cells 2006;24:1294-1301

6. Kim DS, Kim JH, Lee JK, Choi SJ, Kim JS, Jeun SS, Oh W, Yang YS, Chang JW. Overexpression of CXC chemokine receptors is required for the superior glioma-tracking property of umbilical cord blood-derived mesenchymal stem cells. Stem Cells Dev 2009;18:511-519

7. Kim SW, Han H, Chae GT, Lee SH, Bo S, Yoon JH, Lee YS, Lee KS, Park HK, Kang KS. Successful stem cell therapy using umbilical cord blood-derived multipotent stem cells for Buerger's disease and ischemic limb disease animal model. Stem Cells 2006;24:1620-1626

8. Grayson WL, Zhao F, Bunnell B, Ma T. Hypoxia enhances proliferation and tissue formation of human mesenchymal stem cells. Biochem Biophys Res Commun 2007;358:948953
9. Hung SP, Ho JH, Shih YR, Lo T, Lee OK. Hypoxia promotes proliferation and osteogenic differentiation potentials of human mesenchymal stem cells. J Orthop Res 2012; 30:260-266

10. Razban V, Lotfi AS, Soleimani M, Ahmadi H, Massumi M, Khajeh S, Ghaedi M, Arjmand S, Najavand S, Khoshdel A. HIF-1 $\alpha$ overexpression induces angiogenesis in mesenchymal stem cells. Biores Open Access 2012;1:174-183

11. Das R, Jahr H, van Osch GJ, Farrell E. The role of hypoxia in bone marrow-derived mesenchymal stem cells: considerations for regenerative medicine approaches. Tissue Eng Part B Rev 2010;16:159-168

12. Hu X, Yu SP, Fraser JL, Lu Z, Ogle ME, Wang JA, Wei L. Transplantation of hypoxia-preconditioned mesenchymal stem cells improves infarcted heart function via enhanced survival of implanted cells and angiogenesis. J Thorac Cardiovasc Surg 2008;135:799-808

13. Wang JA, Chen TL, Jiang J, Shi H, Gui C, Luo RH, Xie XJ, Xiang MX, Zhang X. Hypoxic preconditioning attenuates hypoxia/reoxygenation-induced apoptosis in mesenchymal stem cells. Acta Pharmacol Sin 2008;29:74-82

14. Luo Z, Wu F, Xue E, Huang L, Yan P, Pan X, Zhou Y. Hypoxia preconditioning promotes bone marrow mesenchymal stem cells survival by inducing HIF-1 $\alpha$ in injured neuronal cells derived exosomes culture system. Cell Death Dis 2019;10:134

15. Liu J, Hao H, Xia L, Ti D, Huang H, Dong L, Tong C, Hou Q, Zhao Y, Liu H, Fu X, Han W. Hypoxia pretreatment of bone marrow mesenchymal stem cells facilitates angiogenesis by improving the function of endothelial cells in diabetic rats with lower ischemia. PLoS One 2015;10: $\mathrm{e} 0126715$

16. Xiong X, Sun Y, Wang X. HIF1A/miR-20a-5p/TGF $\beta 1$ axis modulates adipose-derived stem cells in a paracrine manner to affect the angiogenesis of human dermal microvascular endothelial cells. J Cell Physiol 2020;235:20912101

17. van Es MA, Schelhaas HJ, van Vught PW, Ticozzi N, Andersen PM, Groen EJ, Schulte C, Blauw HM, Koppers M, Diekstra FP, Fumoto K, LeClerc AL, Keagle P, Bloem $B R$, Scheffer $H$, van Nuenen $B F$, van Blitterswijk $M$, van Rheenen W, Wills AM, Lowe PP, Hu GF, Yu W, Kishikawa H, Wu D, Folkerth RD, Mariani C, Goldwurm S, Pezzoli G, Van Damme P, Lemmens R, Dahlberg C, Birve A, Fernández-Santiago R, Waibel S, Klein C, Weber M, van der Kooi AJ, de Visser M, Verbaan D, van Hilten JJ, Heutink P, Hennekam EA, Cuppen E, Berg D, Brown RH Jr, Silani V, Gasser T, Ludolph AC, Robberecht W, Ophoff RA, Veldink JH, Pasterkamp RJ, de Bakker PI, Landers JE, van de Warrenburg BP, van den Berg LH. Angiogenin variants in Parkinson disease and amyotrophic lateral sclerosis. Ann Neurol 2011;70:964-973

18. Whitney KE, Liebowitz A, Bolia IK, Chahla J, Ravuri S, Evans TA, Philippon MJ, Huard J. Current perspectives on biological approaches for osteoarthritis. Ann N Y Acad Sci 2017;1410:26-43 
19. Koay EJ, Athanasiou KA. Hypoxic chondrogenic differentiation of human embryonic stem cells enhances cartilage protein synthesis and biomechanical functionality. Osteoarthritis Cartilage 2008;16:1450-1456

20. Khan WS, Adesida AB, Hardingham TE. Hypoxic conditions increase hypoxia-inducible transcription factor 2alpha and enhance chondrogenesis in stem cells from the infrapatellar fat pad of osteoarthritis patients. Arthritis Res Ther 2007;9:R55

21. Scherer K, Schünke M, Sellckau R, Hassenpflug J, Kurz B. The influence of oxygen and hydrostatic pressure on ar- ticular chondrocytes and adherent bone marrow cells in vitro. Biorheology 2004;41:323-333

22. Lennon DP, Edmison JM, Caplan AI. Cultivation of rat marrow-derived mesenchymal stem cells in reduced oxygen tension: effects on in vitro and in vivo osteochondrogenesis. J Cell Physiol 2001;187:345-355

23. Abdollahi H, Harris LJ, Zhang P, McIlhenny S, Srinivas V, Tulenko T, DiMuzio PJ. The role of hypoxia in stem cell differentiation and therapeutics. J Surg Res 2011;165: $112-117$ 